Article

\title{
Self-Enhancement Driven First-Class Airline Travelers' Behavior: The Moderating Role of Third-Party Certification
}

\author{
Jinkyung Jenny Kim ${ }^{1}{ }^{(D}$, Kwangyong Kim ${ }^{2}$ and Jinsoo Hwang ${ }^{1, *}$ \\ 1 The College of Hospitality and Tourism Management, Sejong University, Seoul 05006, Korea; \\ jennykim1120@gmail.com \\ 2 Korean Standards Association, Seoul 08056, Korea; KimKY@ksa.or.kr \\ * Correspondence: jhwang@sejong.ac.kr
}

Received: 1 May 2019; Accepted: 10 June 2019; Published: 14 June 2019

check for updates

\begin{abstract}
This study was designed with a focus on self-enhancement by flying in first class to understand the intricate associations in the formation of well-being, brand attachment, and word-of-mouth. In addition, this study aimed to examine the moderating effect of third-party certification among consequent variables. For this, data were collected from 199 first-class airline travelers. A quantitative method that was comprised of structural equation modeling and multiple-group analysis wasused to test the research hypotheses. Our findings revealed that both achievement and power were significant drivers of well-being perception of first-class airline travelers and their perceived well-being contributed to building positive brand attachment and word-of-mouth. The association between brand attachment and word-of-mouth was also statistically supported. Furthermore, the moderating role of third-party certification was identified in the causal relationship between well-being perception and brand attachment. Implications were discussed along with diverse approaches for customized and exclusive offerings such as butler services preand post-flights or during transit at airports, and mini stretching sessions in flights to improve self-enhancement during the whole journey of a first-class experience.
\end{abstract}

Keywords: first-class airline travelers; self-enhancement; well-being perception; brand attachment; word-of-mouth; third-party certification

\section{Introduction}

Facilitating self-expressive travelers in the airline industry has increased, since more consumers convey individual identities to distinguish themselves from others by purchasing particular products and services [1]. Airlines began to seek higher yields, which separated passengers into haves and have-nots in the view of revenue management (also known as yield management) [2]. Grading seat classes from the most luxurious, such as firstclass, to economy with a differentiated value proposition has been a wise response to the needs of both consumers and suppliers in the airline industry.

Firstclass is the highest travel class on passenger airlines and it has been recognized as a great revenue generator. For instance, the recent data from the International Air Transport Association (IATA) showed that premium class, which includes both first and business class, accounted for a modest 5.2 percent of the total number of international passengers from 2018, but accounted for a much more significant 30 percent of total airline revenues [3]. The Economist [4] reported that the premium cabins on transatlantic flights accounted for 13 percent of seats but contributed half of the revenue. These statistics indicate the relative importance of first-class airline travelers from the perspective of more revenue out of smaller inventory in comparison to other seat classes. More importantly, a large 
portion is directed to technology development for eco-friendly management, which is a significant expenditure [5]. It is therefore important to understand the triggers of airline travelers flying in first class and the associations with subsequent responses.

Motivationally distinct values according to the circular theory of human values proposed by Schwartz [6] states that four higher order types are categorized, which include self-enhancement, self-transcendence, conservation, and openness to change. Among them, self-enhancement promotes the pursuit of an individual's own interests, and it is composed of achievement and power values [6]. The notion of self-enhancement is when people are motivated to view themselves positively, because they focused on social superiority and esteem. It is one of the most widely embraced assumptions regarding self-concept $[7,8]$. First-class airline travelers have the non-conforming tendencies to consume, because they want to be recognized and treated differently to make them feel special [9]. The higher level seat class is preferred by travelers due to the fact that passengers can receive exclusive and outstanding in-flight services [10]. That is, self-enhancement motives are fundamental to the way researchers view identity, self-esteem, and social relations, and it is virtually impossible to dispense with explanations of psychological phenomena and social behaviors [11]. However, no studies have focused on self-enhancement in the domain of the airline industry, which indicates an urgent need for a better understanding of travelers' value motives in the first-class flights.

Well-being perception has emerged in service marketing literature as the degree to which the consumption of a product or service creates an overall perception of how the quality of life is impacted by the product or service [12]. As consumers have begun to consider products or services that enhance their quality of life, consumer well-being has gained a favorable amount of growing attention. Based on empirical studies, motivational values in conjunction with attitudes were identified as determining factors in building consumers' well-being perceptions in the hospitality field $[13,14]$. Consumers' perception of well-being has been found to be a powerful driver of brand attachment and behavioral intentions [14-17]. Nevertheless, investigating the intricate associations of well-being perception with value motives and its effect in the context of first-class flights remains very limited.

Third-party certification (hereafter TPC) is a regulatory mechanism that differentiates products and services by the attributes and the consistent implementation of standards [18]. Hence, TPC is widely studied as a credible symbol and quality assurance in the domain of the hospitality and tourism industry [18-21]. In particular, the critical role of TPC in explaining consumers' behavior or intentions has been verified and its moderating role has been identified in the relationship between antecedent variables, such as operational the efficiency or effect of warrant, and outcome variables, such as performance or satisfaction. For example, Sparks, Perkins, and Buckley [22] argued that hospitality firms with awards or certificates exert a positive influence on consumers' beliefs about credibility and quality. Kim, Li, and Brymer [23] confirmed the moderating effect of excellence certificates in increasing revenue in the food industry. Despite that, there is little evidence in regard to the moderating role of TPC in the airline industry.

In response to the above research gaps, the purpose of our study was to (1) investigate the effects of self-enhancement by flying in first class on well-being perception, (2) examine the effects of well-being perception on brand attachment and word-of-mouth towards first-class flights, (3) analyze the association between brand attachment and word-of-mouth toward first-class flights, and (4) identify the moderating role of TPC in the causal relationships among consequent variables including well-being perception, brand attachment, and word-of-mouth. In order to achieve the above research purpose, statistical analysis was carried out based on data from 199 first-class passengers. The results of this study are expected to advance our knowledge about the important motivational values of first-class passengers and provide airline practitioners with meaningful insights to develop effective strategies for first-class flights. 


\section{Literature Review}

\subsection{Self-Enhancement by Flying in First Class}

The highly competitive airline markets have induced the needs for a market-oriented approach and in favor of customers who are now becoming more conscious of their needs including self-concept [24]. Psychological characteristics of consumers in the luxury hospitality and tourism context are commonly known as materialism, uniqueness, hedonism, and perfectionism [25,26]. More specifically, consumers with a high level of status value are likely to desire recognition from others and worry about how others view themselves [27]. Consumers purchase luxurious products and services in order for them to be respected by those around them $[28,29]$. As an example, cruise travelers seek to express their economic and social status through traveling on a luxury cruise $[30,31]$. In this regard, the airline industry is not free from active endeavors to distinguish the unique needs of customers flying in first class.

Firstclass is the highest class offered on a passenger jetliner, and it usually refers to a limited number of seats or cabins toward the front of the aircraft that has more space, comfort, service, and privacy. The firstclass on an airline is regarded as a luxurious product and service that implies the extreme end of prestige. It is deemed an exclusive possession of the upper class because of its relatively high price when compared with other classes [32,33]. Firstclass is designed to facilitate travelers with a status symbol and fulfill the expectations of customers who are in need of a luxury experience on an airline.

Values serve as standards that guide the evaluation of events, behaviors, and people, and these self-centered values are ordered by importance relative to one another [34]. Out of the ten motivational values proposed by Schwartz [6], the notion that people are motivated to view themselves positively is a self-enhancement and it is composed of achievement and power human values. Self-enhancement is part of a more general self-orientationversus other-orientation [35], and it has emerged in a variety of ways, such as tendencies to recall information about successes rather than failures, tendencies to think of himself/herself as better than average, and tendencies to have stronger implicit associations between oneself and positive words rather than negative words [11,36,37]. In other words, self-enhancement is a luxury and entails instrumental action designed to promote oneself and one's prospects [11]. Hung and Petrick [30] found that self-enhancement is strengthened by travelers' self-worthy feeling and feeling of consuming a certain tourism product to impress others. For this reason, self-enhancement has been commonly used to explain customer behavior or intentions in the field of luxury products or services.

Luxurious products and services can induce the psychological experience of a feeling of belonging to the upper classes [38]. The classes on the airline according to the consumer are different. The first-class consumers are more self-expressive [39], and wealthy people prefer luxurious products and services, because they emphasize their social status compared to others [27]. In this regard, first-class passengers who are recognized for their uniqueness expect to receive highly luxurious services during the flight as part of their compensation for paying several times more than the other seat classes [9]. As most consumers tend to enhance their achievement and power by purchasing luxurious products or services, self-enhancement is a particularly important motivational value in the first-class flights.

\subsection{Effect of Self-Enhancement on Well-Being Perception}

A lot of studies on values have been aimed atrelatingdifferent individual motivational types of value priorities to differences in attitudes, behavior, and background variables [6]. Self-enhancement motivational value justifies self-serving behavior even at the expense of others [34], and it is comprised of two essential concepts, which include achievement and power [6]. Attaining achievement and power is intricately bound toobtaining the admiration and approval of other people [40]. According to Schwartz [41], the defining goal of achievement is personal success through demonstrating competence according to social standards, whereas the defining goal of power is social status and prestige, control 
of dominance over people, and resources. In other words, achievement generates social approval, and social approval is necessary to attain power [42].

People in the United States have been known to aspire to financial success and such distinction [43, 44]. In fact, in the United States, it is said that "Success is communicated, shared, and displayed, because it is natural to show off" [45]. Indeed, researchers found that US respondents placed importance on achievement and power that is based on independency and unique status [46,47]. It is commonly known that individuals with a high socioeconomic status prefer first-class flights, because the luxury experience offlying in first class helpsto meet their social needs $[13,48,49]$. One of the most important motivations for purchasing a luxurious product or service is achieving social value [33], and it explains high motivational self-enhancement value placed on first-class airline travelers. One of the influencing factors on well-being is grounded in the self-determination theory related to basic psychological needs, personal strivings, and life goals [50-52]. In this regard, the interactive effects of self-enhancement on subsequent variables and the well-being perception have been examined [53-55]. For instance, Sagiv and Schwartz [56] tested the effects of various values on well-being, and they presented the correlations of individuals' attitudes to self-enhancement with their well-being perception. Alicke and Sedikides [11] analyzed self-enhancement grounded on the concept of interests and asserted that self-esteem, which is the focus of both achievement and power, is relevant to virtually all experiences that bear on the well-being of the self.

Achievement indicates personal success through demonstrating normative competence, which thereby obtainssocial approval that emphasizes the active demonstration of successful performance in concrete interaction [6]. Kaplan and Maehr [57] identified that achievement goals are linked with emotions and cognitions that relate to a sense of well-being. Schwartz [58] argued that people endorse achievement with a view to obtaining the admiration and approval of other people, and Sagiv and Schwartz [56] found achievement values are positively related to well-being perception. Job, Langens, and Brandstatter [59] revealed that a relationship between achievement goal striving and high well-being is evident when individuals have a strong corresponding explicit achievement motive. Samuel et al. [55] assessed the interplay between achievement and occupational success and well-being, and found well-being served as an individual resource by fostering achievement and success. These imply that when consumers have a positive achievement flying in first class, they are more likely to enhance their quality of life, which is their well-being perception. Consistent with these arguments, this study developed the following hypothesis.

Hypothesis 1 (H1). Achievement has a positive influence on well-being perception.

Power, which is perhaps the most basic and pervasive feature of human social life, is typically defined as asymmetrical control over other individuals or valued resources in social relations [60]. Power is the transformation of individual needs for dominance and control that emphasize the attainment or preservation of a dominant position within a more general social system [41]. Social, authority, and wealth values are commonly considered as components of power [46].

Several studies based on the self-determination theory supported the theorized associations of extrinsic goal pursuit, which is a power value type, with well-being perception $[50,52]$. Power reduces dependence on other people to acquire and maintain resources, and the possession of power is capable of satisfying their desires without being concerned with how they are viewed by others [61]. Kraus, Chen, and Keltner [62] found that power can increase feelings of authenticity, which is the degree that individuals connect with and enact their true selves in various situations. Kifer et al. [54] asserted that possession of power improves well-being perception by enhancing feelings of authenticity. These arguments are also supported by the notion that individuals' well-being and psychological health can be achieved only by expressing one's true inner thoughts and feelings $[63,64]$. Given this increased correspondence between power and well-being perception, the following hypothesis is proposed.

Hypothesis 2 (H2). Power has a positive influence on well-being perception. 


\subsection{Effect of Well-Being Perception on Brand Attachment and Word-of-Mouth}

Achieving a high level of well-being is considered by many people to be the most valued goal in life $[65,66]$. According to Grzeskowiak and Sirgy [12], a consumer's well-being perception refers to the "consumers' perception of the extent to which a brand positively contributes to a quality of life enhancement." The concept of consumers' well-being perception has received considerable attention due to its important role in making decisions about purchasing products or services [17]. In particular, luxurious products, such as first-classairline tickets and luxury cruises, were verified to enhance individuals' well-being perception $[13,67]$. That is, purchasing prestigious brands is recognized as a way of enhancing subjective quality of life, because purchasing a luxurious product or service reflects a certain degree of wealth and higher level of social status [38].

Well-being perception is often proposed to measure the feeling of brand love $[16,68]$. For this reason, consumers' well-being perception has been widely studied in a variety of service settings such as cruise vacations, hotels, and restaurants, and its effect on managerial outcomes, such as brand attachment. For instance, Hwang and Han [67] examined luxury cruise passengers' well-being perception and identified its positive association with brand identification, which is the degree that a brand is part of a consumer's self-concept. Proksch, Orth, and Cornwell [69] focused on the motivational processes and explained that fulfilling needs leads to individual well-being, which forms stronger consumer attachment to a particular brand. Hwang and Hyun [13] asserted the importance of well-being perception in the airline industry as consumers' needs of well-being would be satisfied by flying in first class, and their brand loyalty is consequently formed. Based on the discussions mentioned above, this study proposes the following hypothesis.

Hypothesis 3 (H3). Well-being perception has a positive influence on brand attachment.

Consumers prefer to purchase products/services that can satisfy well-being needs [17], and their well-being perception plays an important role in predicting behavioral intentions, such as repurchasing experience and spreading positive word-of-mouth [70-72]. When a prestige seeker feels that his/her quality of life is enhanced by consuming a particular product or service, the customer tends to show strong repurchase intentions toward the brand [73-75]. For example, Kim et al. [14] tested 433 pieces of data collected from chain restaurant patrons and the consumers' perception of well-being was proven to be the meaningful driver of dining intentions. Hwang and Han [67] asserted consumers' well-being perception derived from luxury cruises creates brand loyalty, which indicates consistent repeat patronage of a particular brand over time. Hwang and Lyu [76] showed that golf tournament tourists' emotional well-being significantly influences travelers' revisit intentions. Given that well-being perception is an important variable in consumer behavior research, the following hypothesis is formulated.

Hypothesis 4 (H4). Well-being perception has a positive influence on word-of-mouth.

\subsection{Effect of Brand Attachment on Word-of-Mouth}

People have a psychological instinct to rely on particular people or objects [77]. Theoretical background of brand attachment is based on the attachment theory in the psychology literature, which explains the affect-laden bond between an individual and a particular subject [78]. Accordingly, brand attachment refers to the strength of the bond between a brand and a customer, and it represents a long-lasting affective reaction [79].

When consumers are emotionally attached to a particular brand, they are likely to be more supportive of its products/services, and they are willing to be an ambassador of the brand $[31,80]$. For instance, Park, Macinnis, and Priester [81] proposed a conceptual model of brand attachment by explicating significant and positive relationships among brand attachment, consumers' behavioral 
intentions, and behavior. Albert, Merunka, and Valette-Florence [82] illustrated consumer-brand relationship constructs, such as brand passion, brand commitment, and brand attachment, are significantly associated with behavioral intentions such as positive word-of-mouth and willingness to pay more. Hwang and Han [31] revealed that brand attachment built on social value and prestige brands helps to increase a long-term psychological commitment to a certain brand in the domain of a luxury cruise. Therefore, it can be inferred that first-class airline travelers' psychological ties with a first-class product and service are more likely to develop consumers' positive behavior. Based on this evidence, this study posited the positive impact of brand attachment on word-of-mouth.

Hypothesis 5 (H5). Brand attachment has a positive influence on word-of-mouth.

\subsection{Moderating Role of Third-Party Certifiers (TPC)}

Third-party certifiers are private or public organizations responsible for accessing, evaluating, and certifying safety and quality claims based on a particular set of standards and compliance methods [83]. TPC is viewed as more reliable and credible than the first or second-party certifications [84]. Previous research has indicated that accredited certifications serve as a reliable signal of high product/service quality for an organization [23], and independent third-party product information from a credible source is often perceived as being more credible and less biased than marketing cues [85]. The United States Department of Transportation and World Airline Awards are examples of well-known third-party certifiers in the perspective of service and safety quality in the airline industry, and TPCs are regarded as a tool that enables judging of the airlines [86]. TPC reorganizes, transforms, and disciplines people and things throughout the supply chain, which have differential social and economic implications for various participants $[18,87]$. More importantly, provided certifications offer assurances about a product to stakeholders by offering information about the commodity and its production processes for consumers to cope with uncertainty in their purchase decisions [88].

The role of TPC has been widely studied in relation with consumer behavior in the hospitality and tourism context $[19,20,23,89]$. For example, Van der Lans et al. [21] found that TPC in the foodservice industry can affect the product preference through perceived quality. McKinight and Chervany [89] asserted that TPC can increase trusting beliefs based on the nature of the seal, and Kim and Benbasat [90] revealed consumers often base their judgment on the judgement of others, particularly TPC, on internet stores. Akdemiz et al., [88] identified that third-party ratings moderate the effect of warranty on quality perception in consumers' inference-making behaviors. Sparks et al. [22] and Peiró-Signes et al. [20] demonstrated guests' more favorable attitudes and higher satisfaction towards the hotels with TPC than to the ones without certification. Ke, Chen, and Su [91] investigated the e-business platform certification and found it positively moderated the effects of building consumers' trust in the online channel. Kim et al. [23] found that a larger number of reviews or a better overall rating of a restaurant with an excellence certificate promotes net sales, guest counts, and the average bill to a larger degree compared to a restaurant without an excellence certificate. Wang et al. [92] tested the moderating impact of green certification provided by third parties in the field of manufactured products and identified its influence on customers' perceived trust. Integrating the theoretical and empirical backgrounds, the following hypotheses were therefore proposed.

Hypothesis 6a (H6a). TPC moderates the relationship between well-being perception and brand attachment.

Hypothesis $\mathbf{6 b} \mathbf{( H 6 b ) . ~ T P C ~ m o d e r a t e s ~ t h e ~ r e l a t i o n s h i p ~ b e t w e e n ~ w e l l - b e i n g ~ p e r c e p t i o n ~ a n d ~ w o r d - o f - m o u t h . ~}$

Hypothesis 6c (H6c). TPC moderates the relationship between brand attachment and word-of-mouth. 
Our theoretical framework, which includes the moderating role of TPC involves six latent constructs with a total of eighteen measurement items and eight hypotheses. The proposed conceptual model is displayed in Figure 1.

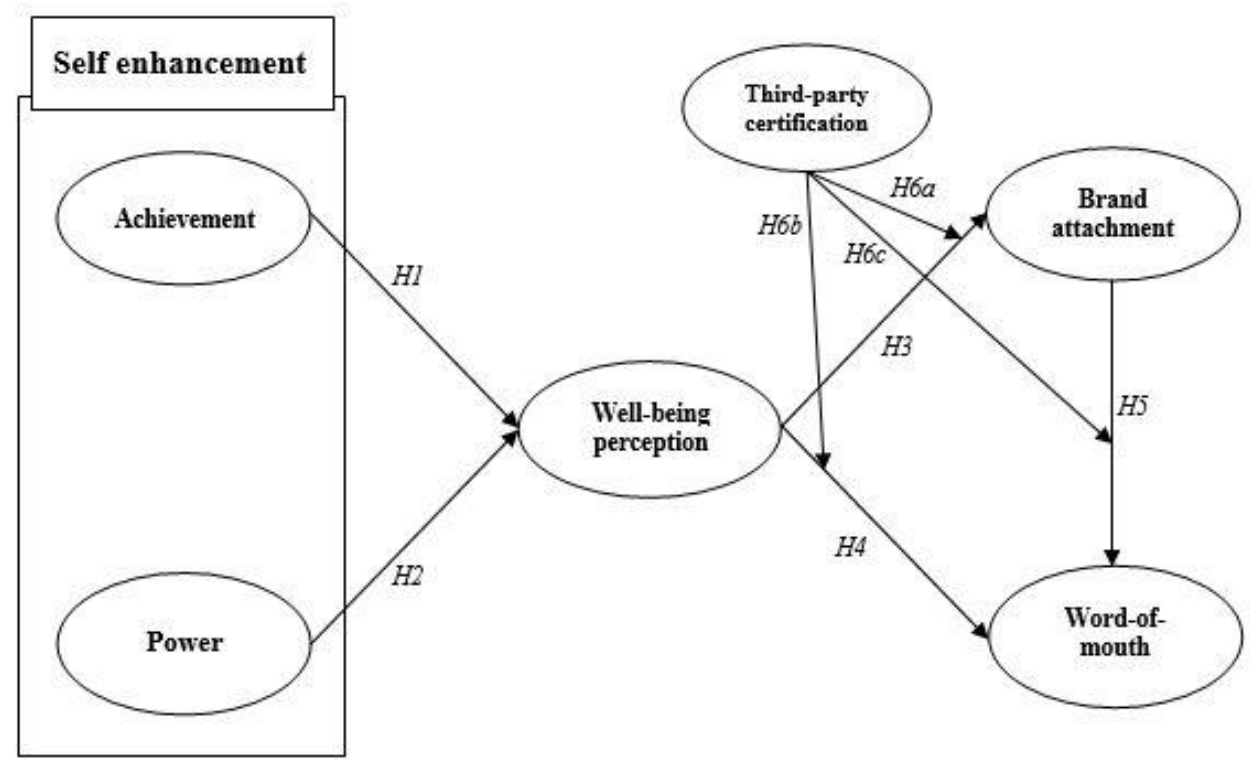

Figure 1. Proposed conceptual model.

\section{Methodology}

\subsection{Measurement}

All the measurement items of the six constructs were generated from validated measurement items and adapted from prior studies. More specifically, self-enhancement consisted of two sub-dimensions, such as achievement and power, and it was measured with six items adapted from Kajonius, Persson, and Jonason [93] and Schultz and Zelezny [94]. Well-being perception was measured with three items borrowed from Grzeskowiak and Sirgy [12] and Hwang and Lyu [76]. Three measurement items for brand attachment were adapted from Carroll and Ahuvia [68] and Vlachos et al. [95] and those for word-of-mouth were from Hennig-Thurau, Gwinner, and Gremler [96] and Zeithaml, Berry, and Parasuraman [97]. Lastly, TPC was measured with three items adapted from Jiang et al. [98] (i.e., "I was aware that this airline is certified by a third party," "I was aware that this airline is ranked one of the top airlines by a third party," and "I was aware that this airline has received awards from public/private organizations"). All items were measured based on a five-point Likert's scale, which was anchored from strongly disagree (1) to strongly agree (5).

\subsection{Data Collection}

A web-based survey was performed for the data collection. Questionnaires were sent to 1645 first-class passengers using a market research firm in the US. As a result, a total of 209 first-class passengers, who hadflown first-class in the past three months, participated in the survey. In addition, 10 samples were excluded from the statistical analysis because of multicollinearity problems and visual inspections. Lastly, the statistical analysis was conducted based on 199 samples.

\section{Data Analysis}

\subsection{Descriptive Statistics}

Table 1 represents the respondents' demographic profiles. Among the 199 respondents, 143 $(71.9 \%)$ were male and $56(28.1 \%)$ were female. The mean age was 49.01 years old. In terms of annual 
household income, the largest respondent group reported $\$ 200,000$ and over $(n=77,38.7 \%)$. More than half of the samples were married $(n=172,86.4 \%)$. Regarding education, the largest group had a fouryear college degree $(n=103,51.8 \%)$, which was followed by a graduate degree $(n=78,39.2 \%)$. In addition, the largest respondent group showed that they wereCaucasian/White. Finally, $134(67.3 \%)$ were company employees.

Table 1. Respondent profile $(n=199)$.

\begin{tabular}{|c|c|c|}
\hline Variable & $n$ & $\%$ \\
\hline Gender & 143 & 71.9 \\
\hline $\begin{array}{c}\text { Male } \\
\text { Female }\end{array}$ & 56 & 28.1 \\
\hline \multicolumn{3}{|l|}{ Age $($ Mean $=49.01$ year old $)$} \\
\hline $30 \mathrm{~s}$ & 50 & 25.1 \\
\hline $40 \mathrm{~s}$ & 52 & 26.1 \\
\hline $50 \mathrm{~s}$ & 56 & 28.1 \\
\hline 60 or older & 41 & 20.6 \\
\hline \multicolumn{3}{|l|}{ Education Level } \\
\hline High school diploma & 3 & 1.5 \\
\hline Some college but no degree & 7 & 3.5 \\
\hline Associate's degree & 8 & 4.0 \\
\hline Bachelor's degree & 103 & 51.8 \\
\hline Graduate degree & 78 & 39.2 \\
\hline \multicolumn{3}{|l|}{ Marital Status } \\
\hline Single & 48 & 9.0 \\
\hline Married & 172 & 86.4 \\
\hline Widowed & 4 & 2.0 \\
\hline Divorced & 5 & 2.5 \\
\hline \multicolumn{3}{|l|}{ IncomeLevel } \\
\hline$\$ 200,000$ and over & 77 & 38.7 \\
\hline$\$ 175,000-\$ 199,999$ & 28 & 14.1 \\
\hline$\$ 150,000-\$ 174,999$ & 25 & 12.6 \\
\hline Under $\$ 149,999$ & 69 & 34.7 \\
\hline \multicolumn{3}{|l|}{ Race } \\
\hline African American & 5 & 2.5 \\
\hline Asian & 8 & 4.0 \\
\hline Hispanic & 6 & 3.0 \\
\hline Caucasian/White & 177 & 88.9 \\
\hline Other & 3 & 1.5 \\
\hline \multicolumn{3}{|l|}{ Occupation } \\
\hline Company employee & 134 & 67.3 \\
\hline Own business & 31 & 15.6 \\
\hline Sales/service & 3 & 1.5 \\
\hline Student & 1 & .5 \\
\hline Housewife & 8 & 4.0 \\
\hline No job & 6 & 3.0 \\
\hline Other & 16 & 8.0 \\
\hline
\end{tabular}

\subsection{Confirmatory Factor Analysis}

A confirmatory factor analysis (CFA) was performed to identify the unidimensionality of scales measuring six constructs, which included achievement, power, well-being perception, brand attachment, word-of-mouth, and TPC. The results of the CFA revealed that the measurement model provided an 
acceptable fit $\left(\chi^{2}=285.133, d f=118, p<0.001, \chi^{2} / d f=2.416\right.$, Normed Fit Index (NFI) $=0.944$, Comparative Fit Index $(\mathrm{CFI})=0.966$, Incremental Fit Index (IFI) $=0.967$, Tucker-Lewis Index $(\mathrm{TLI})=0.956$, and Root Mean Square Error of Approximation (RMSEA) $=0.085$ ) [99]. Table 2 provides the variables used in the analysis and their standardized factor loadings. The factor loadings were higher than or equal to 0.775 , and all were significant at $p<0.001$.

Table 2. Confirmatory factor analysis: Items and loadings.

\begin{tabular}{|c|c|}
\hline Construct and Scale Item & StandardizedLoading $^{\mathrm{a}}$ \\
\hline \multicolumn{2}{|l|}{ Self-Enhancement } \\
\hline \multicolumn{2}{|l|}{ Achievement } \\
\hline When I fly in first class, I feel that I have achieved success in my life. & 0.775 \\
\hline When I fly in first class, I feel that I achieved a good social position. & 0.859 \\
\hline Flying in first class helps to preserve my public image. & 0.971 \\
\hline \multicolumn{2}{|l|}{ Power } \\
\hline Flying in first class makes me feel that I have social power over other people. & 0.964 \\
\hline Flying in first class makes me feel more influential over others. & 0.979 \\
\hline Flying in first class makes me feel that I have charisma over other people. & 0.981 \\
\hline \multicolumn{2}{|l|}{ Well-Being Perception } \\
\hline Flying with this airline met my overall well-being needs. & 0.968 \\
\hline Flying with this airline played a very important role in my social well-being. & 0.954 \\
\hline Flying with this airline played an important role in my travel well-being. & 0.938 \\
\hline \multicolumn{2}{|l|}{ Brand Attachment } \\
\hline Taking a first-class flight makes me feel good. & 0.955 \\
\hline Taking a first-class flight makes me very happy. & 0.944 \\
\hline I love taking a first-class flight. & 0.882 \\
\hline \multicolumn{2}{|l|}{ Word-of-Mouth } \\
\hline I would say positive things about this airline brand to others. & 0.933 \\
\hline I recommend this airline brand to people who seek my advice. & 0.974 \\
\hline I encourage friends and relatives to take this airline. & 0.883 \\
\hline \multicolumn{2}{|l|}{ Third-Party Certification } \\
\hline $\begin{array}{l}\text { I was aware that this airline is certified by a third party (e.g., United States } \\
\text { Department of Transportation). }\end{array}$ & 0.902 \\
\hline $\begin{array}{l}\text { I was aware that this airline is ranked one of the top airlines by a third party } \\
\text { (e.g., Skytrax's STAR Ranking system). }\end{array}$ & 0.984 \\
\hline $\begin{array}{l}\text { I was aware that this airline has received awards from public/private } \\
\text { organizations (e.g., World Airline Awards, International Flight Catering } \\
\text { Association's Mercury Award). }\end{array}$ & 0.956 \\
\hline \multicolumn{2}{|c|}{$\begin{array}{l}\text { Goodness-of-fit statistics: } \chi^{2}=285.133, d f=118, p<0.001, \chi^{2} / d f=2.416, \mathrm{NFI}=0.944, \mathrm{CFI}=0.966, \mathrm{IFI}=0.967 \\
\text { TLI }=0.956, \text { and RMSEA }=0.085\end{array}$} \\
\hline
\end{tabular}

As indicated in Table 3, the values of average variance extracted (AVE) for the six constructs were greater than the satisfactory threshold of 0.50 [99]. These results suggested a high level of convergent validity for the measurement scales. The composite reliability of the constructs was also higher than 0.70, ranging from 0.904 to 0.984 . This indicated sufficient internal consistency for all the constructs in the model [100]. Finally, discriminant validity was checked through the comparison of the values of AVE and squared correlations between the two constructs of interest [99]. All values of AVE for each construct exceeded all squared correlations $\left(R^{2}\right)$ between any pair of constructs, which suggested a high level of discriminant validity. 
Table 3. Descriptive statistics and associated measures.

\begin{tabular}{lccccccccc}
\hline & $\begin{array}{c}\text { No. of } \\
\text { Items }\end{array}$ & $\begin{array}{c}\text { Mean } \\
\text { (Std Dev.) }\end{array}$ & AVE & (1) & (2) & (3) & (4) & (5) & (6) \\
\hline (1) Achievement & 3 & $3.22(1.15)$ & 0.760 & $\mathbf{0 . 9 0 4}^{\mathrm{a}}$ & $0.806^{\mathrm{b}}$ & 0.701 & 0.376 & 0.200 & 0.450 \\
(2) Power & 3 & $2.89(1.33)$ & 0.950 & $0.650^{\mathrm{c}}$ & $\mathbf{0 . 9 8 4}$ & 0.657 & 0.278 & 0.155 & 0.476 \\
(3) Well-being perception & 3 & $3.55(.86)$ & 0.909 & 0.491 & 0.432 & $\mathbf{0 . 9 6 8}$ & 0.472 & 0.465 & 0.496 \\
(4) Brand attachment & 3 & $3.88(.87)$ & 0.860 & 0.141 & 0.077 & 0.223 & $\mathbf{0 . 9 4 9}$ & 0.425 & 0.153 \\
(5) Word-of-mouth & 3 & $3.94(.72)$ & 0.866 & 0.040 & 0.024 & 0.216 & 0.181 & $\mathbf{0 . 9 5 1}$ & 0.349 \\
(6) Third-party certification & 3 & $3.02(1.27)$ & 0.899 & 0.202 & 0.226 & 0.246 & 0.023 & 0.121 & $\mathbf{0 . 9 6 4}$ \\
\hline
\end{tabular}

Notes 1: All correlations among study variables are significant at $p<0.01$. Notes 2: AVE $=$ Average Variance ExtractedNotes 3: ${ }^{a}$ Composite reliabilities are along the diagonal, ${ }^{b}$ correlations are above the diagonal, and ${ }^{\mathrm{c}}$ squared correlations are below the diagonal.

\subsection{Structural Model}

The proposed model with five hypotheses was evaluated by structural equation modeling (SEM). The results of SEM revealed that the model had a suitable fit to the data $\left(\chi^{2}=194.413, d f=81, p<0.001\right.$, $\chi^{2} / d f=2.400, \mathrm{NFI}=0.954, \mathrm{CFI}=0.973, \mathrm{IFI}=0.973, \mathrm{TLI}=0.964$, and RMSEA $=0.084$ ) [101]. Figure 2 shows the SEM results with standardized coefficients. The results provided significant support for all the proposed hypotheses at $p<0.05$. Table 4 provides a summary of the results.

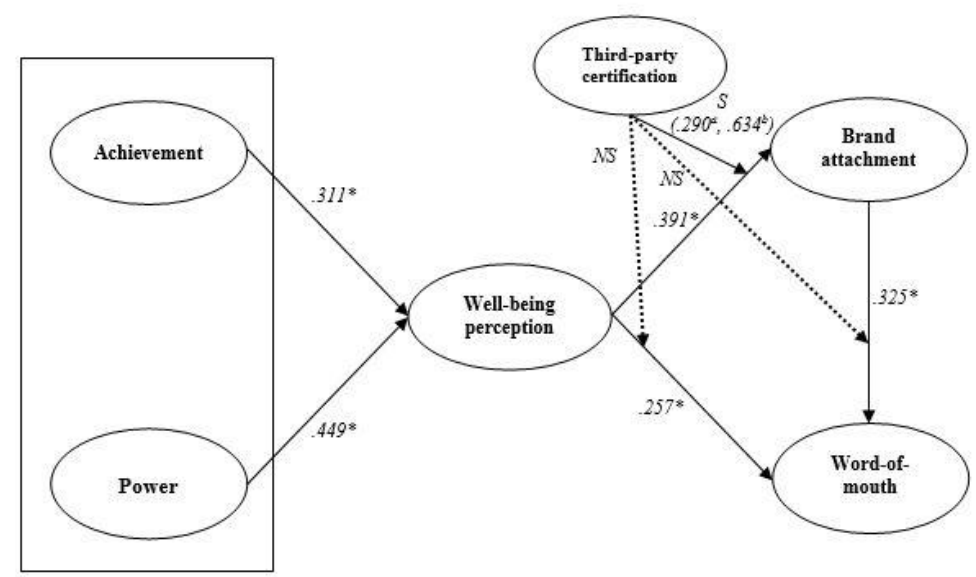

Figure 2. Standardized theoretical path coefficients. Notes $1 .{ }^{*} p<0.05 ; \mathrm{S}=$ significant; NS = not significant. Notes 2. a: path coefficient for a low third-party certification group; b: path coefficient for a high third-party certification group.

Table 4. Standardized parameter estimates for structural model.

\begin{tabular}{|c|c|c|c|c|c|}
\hline \multicolumn{3}{|c|}{ Paths } & \multirow{2}{*}{$\begin{array}{c}\begin{array}{c}\text { Standardized } \\
\text { Estimate }\end{array} \\
0.311\end{array}$} & \multirow{2}{*}{$\begin{array}{c}t \text {-Value } \\
2.955\end{array}$} & \multirow{2}{*}{$\begin{array}{l}\text { Hypothesis } \\
\text { Supported }\end{array}$} \\
\hline H1: Achievement & $\rightarrow$ & Well-being perception & & & \\
\hline H2: Power & $\rightarrow$ & Well-being perception & 0.449 & 4.176 & Supported \\
\hline H3: Well-being perception & $\rightarrow$ & Brand attachment & 0.391 & 5.804 & Supported \\
\hline H4: Well-being perception & $\rightarrow$ & Word-of-mouth & 0.257 & 3.758 & Supported \\
\hline H5: Brand attachment & $\rightarrow$ & Word-of-mouth & 0.325 & 4.515 & Supported \\
\hline \multicolumn{5}{|c|}{$\begin{array}{l}\text { H6a: The moderating effect of third-party certification in the relationship between well-being } \\
\text { perception and brand attachment }\end{array}$} & Supported \\
\hline \multicolumn{5}{|c|}{$\begin{array}{l}\text { H6b: The moderating effect of third-party certification in the relationship between well-being } \\
\text { perception and word-of-mouth }\end{array}$} & Not supported \\
\hline \multicolumn{5}{|c|}{$\begin{array}{l}\text { H6c: The moderating effect of third-party certification in the relationship between brand } \\
\text { attachment and word-of-mouth }\end{array}$} & Not supported \\
\hline \multicolumn{6}{|c|}{$\begin{array}{l}\text { Goodness-of-fit statistics: } \chi^{2}=194.413, d f=81, p<0.001, \chi^{2} / d f=2.400, \mathrm{NFI}=0.954, \mathrm{CFI}=0.973, \mathrm{IFI}=0.973 \text {, } \\
\mathrm{TLI}=0.964, \text { and RMSEA }=0.084\end{array}$} \\
\hline
\end{tabular}

Note: NFI = Normed Fit Index, CFI = Comparative Fit Index, IFI = Incremental Fit Index, TLI = Tucker-Lewis Index, RMSEA = Root Mean Square Error of Approximation. 


\subsection{The Moderating Effect of TPC}

This study used multi-group analyses to examine the moderating effects of TPC. First, the sample ( $n=199)$ was divided into two groups: a low TPC group $(n=101)$ and a high TPC group $(n=98)$. As suggested by Anderson and Gerbing [102], the chi-square difference between the two models, such as the constrained and unconstrained models, was evaluated based on the differences in the degree of freedom. First, the moderating effect of TPC on the relationship between well-being perception and brand attachment was assessed (H6a). The chi-square difference between the two models including the constrained and unconstrained models was significant at the 0.05 level $\left(\chi^{2}=10.897>\chi^{2} 0.05(1)=3.84\right.$, $d f=1$ ), which suggested support for Hypothesis 6a. With respect to the high TPC group, the path coefficient was $0.634(p<0.05)$, whereas for the low TPC group, it was $0.290(p<0.05)$. However, in the case of Hypothesis $6 \mathrm{~b}$ (the moderating effect of TPC on the relationship between well-being perception and word-of-mouth) and Hypothesis $6 \mathrm{c}$ (the moderating effect of TPC on the relationship brand attachment and word-of-mouth), the chi-square differences between the two models were not significant at the 0.05 level, which indicated no support for Hypothesis $6 \mathrm{~b}$ and $6 \mathrm{c}$.

\section{Discussions and Implications}

In hopes of providing unique insights into first-classairline travel, the present study built the theoretical framework focused on motivational human values, particularly self-enhancement, in order to examine associations among key variables that induced favorable behavior of first-class travelers. In addition, this study aimed to identify the role of TPCand if the assurance offered to an airline company by a third party moderated the causal relationships between well-being perception and brand attachment, well-being perception and word-of-mouth, and brand attachment and word-of-mouth. The data analyses to test the research hypotheses were conducted based on the survey collected from 199 respondents who had flown first class in the past three months. Both achievement and power, which are sub-dimensions of self-enhancement, increased well-being perception, and Hypotheses 1 and 2 were supported accordingly. Well-being perception showed a positive effect on brand attachment (Hypothesis 3) and word-of-mouth (Hypothesis 4), and a significant and positive association was also found between brand attachment and word-of-mouth (Hypothesis 5). Moreover, the moderating role of TPC was identified in the relationship between well-being perception and brand attachment (Hypothesis 6a). More specifically, the causal impact of well-being perception on brand attachment grew stronger in the high TPC group than in the low TPC group. This research is invaluable for its approach to how motivational values drive customers' perceived well-being in inducing a positive behavior together with the moderating role of TPC and the novelty it presents in the domain of first-class flights. The results of this study provided the following critical theoretical and managerial implications in the airline industry.

\subsection{Theoretical Implications}

In the extent of luxury market research, scholars have postulated the importance placed on motivational human values, and consumers' self-concept related to esteem, social status, and prestige was often considered in explicating the process of behavior formation over all $[27,28,33]$. Our study results support the evidence of existing literature by indicating self-enhancement composed of achievement $(\beta=0.311, p<0.05)$ and power $(\beta=0.449, p<0.05)$ contributed to building the well-being perception of first-class airline travelers. Airline travelers who possess a high level of social superiority and esteem are likely to increase well-being perception by flying in firstclass. Although both achievement and power represent self-enhancement according to Schwartz [6], these two key determinants are not statistically supported in building well-being perception at the same time in every setting [56], implying that self-enhancement values play a critical role in first-class flights. It is therefore apparent that airline practitioners should focus on approaches to distinguish first-class travelers from others by differentiation and provide a unique customer experience to fulfill their motives of 
achievement and power and consequently improve self-enhancement. This result is theoretically meaningful by tapping the motivational human values, and more importantly self-enhancement in the context of first-class flights, which has rarely been conducted. With respect to viewing the psychological aspect of consumers' choice in purchasing luxurious products and services in the airline industry, this study contributed to the broad current knowledge in the field.

Second, first-class passengers' well-being perception $(\beta=0.391, p<0.05)$ positively influences their brand attachment. This finding supported the results examined by Hwang and Han [67] and Hwang and Hyun [13], and it proved the salient role of well-being perception in forming brand attachment in an airline service setting. In other words, airline travelers' enhanced well-being perception fromflying in firstclass is a vital trigger in creating an intense bond between a customer and a particular product or service. In addition, well-being perception $(\beta=0.257, p<0.05)$ showed a positive effect on favorable word-of-mouth fromfirst-class airline travelers, and it is coherent with the study of Dagger and Sweeney [68] and Sirgy et al. [72]. Accordingly, this study confirmed and further extended the existing literature by verifying the causal relationships between well-being perception and brand attachment and well-being perception and word-of-mouth in the airline industry, which more specifically included first-class flights.

The last important theoretical contribution of this study is the identified moderating role of TPC for the first time in anairline context. Our analyses found that the causal link from first-class travelers' well-being perception to brand attachment significantly differed depending on the acknowledged level of TPC. More specifically, the association between well-being perception and brand attachment was stronger in the high TPC group than in the low TPC group (high: $\beta=0.634, p<0.05$ vs. low: $\beta=0.290$, $p<0.05)$. This result implied that TPC is regarded as a reliable and credible signal of a well-qualified product and service in the airline industry, and well-being perception of first-class travelers who highly acknowledge TPC is an essential driver in strengthening the attachment to a particular brand. However, unlike our predictions, the moderating effect of TPC was not found in the relationship between well-being perception and word-of-mouth, and brand attachment and word-of-mouth. These results may be attributed to the fact that word-of-mouth is triggered by travelers'own evaluation and their personal ties [90] rather than second or third-party evaluations. Regardless, this study is the first known research to uncover the moderating role of TPC in the domain of the airline industry, research into which has not been conducted as of yet and a theoretical base is yet to be established.

\subsection{Managerial Implications}

First and foremost, both achievement and power showed positive effects on first-class airline travelers' well-being perception. This implies the importance that first-class patrons' placed on self-enhancement and suggests that airline companies should recognize achievement and power as a vital motivational value of first-class passengers and pay extra attention to ensuring the products and services fulfill travelers' desires. Thus, it is necessarynot only to supply a comfortable full-size bed, a pleasant atmosphere, and a seamless service, but also personalized exclusive offerings and distinctive intangible touches to enhance the first-class experience in order to improve passengers' perceived achievement and power compared to others. This would begin from the point of flight reservation or check-in where first-class passengers can select their own key attributes that they feel are important and valuable, and it has to last until the end by making sure that travelers are safely settled at their destination. Pre-ordering meal services for first-class passengers is now commonplace in many airlines. However, more categories, such as interesting inflight amenities, and likes or dislikes, for travelers to select their preference and requirements in advance are recommended. Furthermore, available butler services pre and post flights or during transition at an airport could be one excellent extension to the current ground services, such as limo transfers and dedicated lounges, to provide end-to-end comfort, especially for long-haul first class. First-class products can be modified to be customizable and services can be tailor-made for travelers so theyfeel special and unique by using those services. 
Second, well-being perception had a positive effect on brand attachment. If airline travelers enhance their quality of life by flying in firstclass, they tend to have an attachment to a particular airline product or service. The first-class airline marketing should focus on illuminating the high level of quality of life that first-class passengers experience during prolonged periods of sitting or lying down in aflight. For instance, in-flight food and beverages should be developed to improve the wellness of organic products and cooking methods, and these can be further upgraded by meeting each individual's special needs, such as food restrictions or diets. Mini stretching sessions to practice in the seat during the flight could be one option in addition to the emerging airline lounges, which provide yoga [103]. Furthermore, a variety of efforts in travelers' daily lives would be helpful to make them feel that their well-being is being concentrated on, and they are valued customers at all times. For example, well-being perception can be accelerated by inviting repeat first-class travelers to special wellness programs, such as a meditation hosted by a renowned expert or exclusive events, such as an advisory board for in-flight well-being food selection, that create a feeling of belonging to a high level of society with an increased well-being perception. More importantly, enhancing well-being perception of first-class passengers would be a great help inacquiring new customers and developing retention strategies for first-class flights based on the significant associations of both well-being perception and brand attachment with word-of-mouth.

Third, the results of the multiple-group analyses indicated that the relationship between well-being perception and brand attachment was under the significant influence of TPC. When first-class passengers know a lot more about awarded TPC, the intensity of causal relationships between well-being perception and brand attachment is more likely to be strong. Hence, airline practitioners should seek the opportunities to gain TPCs by taking serious reviews of evaluation criteria of such TPCs and diagnose their shortcomings and weaknesses to plan ahead. Moreover, effective advertisements of received TPC are suggested to accelerate the positive effect of well-being perception on brand attachment. Emotional advertising is commonly known for its effectiveness in consumer-brand relationship in the airline industry [104,105], and the direct message of TPC should be restricted to certain areas, such as a regular newsletter to members and a public statement, but promoting awarded TPC could be utilized in conjunction with a company slogan or a logo adjunct to the emotionally appealing advertisement or indirect casual ways on social networking services (SNS).

\section{Limitations and Future Research}

Despite the insightful implications based on the empirical findings of this study, a few limitations should be noted. First, the data utilized in this study was collected from first-class airline travelers in the US. There is a growing body of studies that indicate that such a self-enhancement effect is greatly attenuated, and it is completely reversed in non-western cultures, such as Asian cultures, in some cases $[43,106]$. Therefore, additional research is necessary as a comparative perspective to provide more specific marketing implications toward different nationalities or people in different cultural backgrounds and with individualism versus collectivism. Second, selection biases may exists, because an online survey system was used, and therefore future research needs to use different types of data collection methods, such as a field survey. The last limitation of this study is the relatively small sample size, a larger sample size is recommended for future studies to provide a more powerful statistical support of the multi-group analyses [100].

Author Contributions: Conceptualization, J.J.K.; Formal analysis, K.K.; Methodology, J.H.; Writing-original draft, J.J.K.; Writing-review \& editing, J.H.

Funding: This research received no external funding.

Conflicts of Interest: The authors declare no conflict of interest. 


\section{References}

1. Essays, UK. Consumer Behavior Trends and Their Impacts on Airline Marketing Essay. Available online: https://www.ukessays.com/essays/marketing/consumer-behavior-trends-and-their-impacts-onairline-marketing-essay.php?vref=1 (accessed on 31 March 2019).

2. McGill, J.I.; Van Ryzin, G.J. Revenue management: Research overview and prospects. Transp. Sci. 1999, 33, 233-256. [CrossRef]

3. IATA. Airlines Financial Monitor. Available online: https://www.iata.org/publications/economics/reports/ afm/airlines-financial-monitor-feb-2019.pdf (accessed on 31 March 2019).

4. The Economist. First-Class Air Travel Is in Decline. Available online: https://www.economist.com/ international/2019/03/09/first-class-air-travel-is-in-decline (accessed on 31 March 2019).

5. Lee, K.C.; Tsai, W.H.; Yang, C.H.; Lin, Y.Z. An MCDM approach for selecting green aviation fleet program management strategies under multi-resource limitations. J. Air Transp. Manag. 2018, 68, 76-85. [CrossRef]

6. Schwartz, S.H. Universals in the content and structure of values: Theoretical advances and empirical tests in 20 countries. In Advancesin Experimental Social Psychology; Academic Press: New York, NY, USA, 1992; Volume 25, pp. 1-65.

7. Maslow, A.H. A theory of human motivation. Psychol. Rev. 1943, 50, 370. [CrossRef]

8. Taylor, S.E.; Brown, J.D. Illusion and well-being: A social psychological perspective on mental health. Psychol. Bull. 1988, 103, 193. [CrossRef] [PubMed]

9. Hwang, J.; Hyun, S.S. First-class airline travelers' tendency to seek uniqueness: How does it influence their purchase of expensive tickets? J. Travel Tour. Mark. 2017, 34, 935-947. [CrossRef]

10. An, M.; Noh, Y. Airline customer satisfaction and loyalty: Impact of in-flight service quality. Serv. Bus. 2009, 3, 293-307. [CrossRef]

11. Alicke, M.D.; Sedikides, C. Self-enhancement and self-protection: What they are and what they do. Eur. Rev.Soc. Psychol. 2009, 20,1-48. [CrossRef]

12. Grzeskowiak, S.; Sirgy, M.J. Consumer well-being (CWB): The effects of self-image congruence, brand-community belongingness, brand loyalty, and consumption recency. Appl. Res. Qual. Life 2007, 2, 289-304. [CrossRef]

13. Hwang, J.; Hyun, S.S. First-class airline travellers' perception of luxury goods and its effect on loyalty formation. Curr. Issues Tour. 2017, 20, 497-520. [CrossRef]

14. Kim, I.; Jeon, S.M.; Hyun, S.S. Chain restaurant patrons' well-being perception and dining intentions: The moderating role of involvement. Int. J. Contemp. Hosp. Manag. 2012, 24, 402-429. [CrossRef]

15. Han, H.; Kiatkawsin, K.; Jung, H.; Kim, W. The role of wellness spa tourism performance in building destination loyalty: The case of Thailand. J. Travel Tour. Mark. 2018, 35, 595-610. [CrossRef]

16. Ismail, A.R.; Spinelli, G. Effects of brand love, personality and image on word of mouth: The case of fashion brands among young consumers. J. Fash. Mark. Manag. Int. J. 2012, 16, 386-398.

17. Sirgy, M.J.; Lee, D.J.; Rahtz, D. Research on consumer well-being (CWB): Overview of the field and introduction to the special issue. J. Macromark. 2007, 27, 341-349. [CrossRef]

18. Hatanaka, M.; Bain, C.; Busch, L. Third-party certification in the global agrifood system. Food Policy 2005, 30, 354-369. [CrossRef]

19. Darnall, N.; Ji, H.; Vázquez-Brust, D.A. Third-party certification, sponsorship, and consumers' ecolabel use. J. Bus. Ethics. 2018, 150, 953-969. [CrossRef]

20. Peiró-Signes, A.; Segarra-Oña, M.D.V.; Verma, R.; Mondéjar-Jiménez, J.; Vargas-Vargas, M. The impact of environmental certification on hotel guest ratings. Cornell Hosp. Q. 2014, 55, 40-51. [CrossRef]

21. Van der Lans, I.A.; Van Ittersum, K.; De Cicco, A.; Loseby, M. The role of the region of origin and EU certificates of origin in consumer evaluation of food products. Eur. Rev. Agric. Econ. 2001, 28, 451-477. [CrossRef]

22. Sparks, B.A.; Perkins, H.E.; Buckley, R. Online travel reviews as persuasive communication: The effects of content type, source, and certification logos on consumer behavior. Tour. Manag. 2013, 39, 1-9. [CrossRef]

23. Kim, W.G.; Li, J.J.; Brymer, R.A. The impact of social media reviews on restaurant performance: The moderating role of excellence certificate. Int. J. Hosp. Manag. 2016, 55, 41-51. [CrossRef]

24. Teichert, T.; Shehu, E.; von Wartburg, I. Customer segmentation revisited: The case of the airline industry. Transp. Res. Part A Policy Pract. 2008, 42, 227-242. [CrossRef] 
25. Han, H.; Meng, B.; Chua, B.L.; Ryu, H.B.; Kim, W. International volunteer tourism and youth travelers-an emerging tourism trend. J. Travel Tour. Mark. 2019, 36, 549-562. [CrossRef]

26. Lee, J.H.; Hwang, J. Luxury marketing: The influences of psychological and demographic characteristics on attitudes toward luxury restaurants. Int. J. Hosp. Manag. 2011, 30, 658-669. [CrossRef]

27. Dubois, B.; Czellar, S. Prestige brands or luxury brands? An exploratory inquiry on consumer perceptions. In Proceedings of the European Margketing Academy 31st Conference, Braga, Portugal, 28-31 May 2002; University of Minho: Braga, Portugal, 2002.

28. Han, H.; Hyun, S.S. Role of motivations for luxury cruise traveling, satisfaction, and involvement in building traveler loyalty. Int. J. Hosp. Manag. 2018, 70, 75-84. [CrossRef]

29. Okonkwo, U. Sustaining the luxury brand on the Internet. J. Brand Manag. 2009, 16, 302-310. [CrossRef]

30. Hung, K.; Petrick, J.F. Why do you cruise? Exploring the motivations for taking cruise holidays, and the construction of a cruising motivation scale. Tour. Manag. 2011, 32, 386-393. [CrossRef]

31. Hwang, J.; Han, H. A study on the application of the experience economy to luxury cruise passengers. Tour. Hosp. Res. 2018, 18, 478-491. [CrossRef]

32. Hwang, J.; Lyu, S.O. Understanding first-class passengers' luxury value perceptions in the US airline industry. Tour. Manag. Perspect. 2018, 28, 29-40. [CrossRef]

33. Wiedmann, K.P.; Hennigs, N.; Siebels, A. Value-based segmentation of luxury consumption behavior. Psychol. Mark. 2009, 26, 625-651. [CrossRef]

34. Lönnqvist, J.E.; Walkowitz, G.; Verkasalo, M.; Wichardt, P.C. Situational power moderates the influence of self-transcendence vs. self-enhancement values on behavior in ultimatum bargaining. J. Res. Personal. 2011, 45, 336-339. [CrossRef]

35. Campbell, W.K.; Reeder, G.D.; Sedikides, C.; Elliot, A.J. Narcissism and comparative self-enhancement strategies. J. Res. Personal. 2000, 34, 329-347. [CrossRef]

36. Byun, J.; Jang, S.S. “To compare or not to compare?": Comparative appeals in destination advertising of ski resorts. J. Destin. Mark. Manag. 2018, 10, 143-151. [CrossRef]

37. Greenwald, A.G.; Farnham, S.D. Using the implicit association test to measure self-esteem and self-concept. J. Personal. Soc. Psychol. 2000, 79, 1022. [CrossRef]

38. Steenkamp, J.B.E.; Batra, R.; Alden, D.L. How perceived brand globalness creates brand value. J. Int. Bus. Stud. 2003, 34, 53-65. [CrossRef]

39. Hares, A.; Dickinson, J.; Wilkes, K. Climate change and the air travel decisions of UK tourists. J. Transp. Geogr. 2010, 18, 466-473. [CrossRef]

40. Grouzet, F.M.; Kasser, T.; Ahuvia, A.; Dols, J.M.F.; Kim, Y.; Lau, S.; Sheldon, K.M. The structure of goal contents across 15 cultures. J. Personal. Soc. Psychol. 2005, 89, 800. [CrossRef] [PubMed]

41. Schwartz, S.H. An overview of the Schwartz theory of basic values. Online Read. Psychol. Cult. $2012,2,11$. [CrossRef]

42. Pulfrey, C.; Butera, F. Why neoliberal values of self-enhancement lead to cheating in higher education: A motivational account. Psychol. Sci. 2013, 24, 2153-2162. [CrossRef] [PubMed]

43. Kitayama, S.; Markus, H.R.; Matsumoto, H.; Norasakkunkit, V. Individual and collective processes in the construction of the self: Self-enhancement in the United States and self-criticism in Japan. J. Personal. Soc. Psychol. 1997, 72, 1245. [CrossRef]

44. Markus, H.R.; Kitayama, S. Culture and the self: Implications for cognition, emotion, and motivation. Psychol. Rev. 1991, 98, 224. [CrossRef]

45. De Mooij, M. Global Marketing and Advertising; Sage: Thousand Oaks, CA, USA, 1998.

46. Nelson, M.R.; Shavitt, S. Horizontal and vertical individualism and achievement values: A multimethod examination of Denmark and the United States. J. Cross-Cult. Psychol. 2002, 33, 439-458. [CrossRef]

47. Oishi, S.; Schimmack, U.; Diener, E.; Suh, E.M. The measurement of values and individualism-collectivism. Personal. Soc. Psychol. Bull. 1998, 24, 1177-1189. [CrossRef]

48. Belk, R.W. Possessions and the extended self. J. Consum. Res. 1988, 15, 139-168. [CrossRef]

49. Chua, B.L.; Kim, H.C.; Lee, S.; Han, H. The role of brand personality, self-congruity, and sensory experience in elucidating sky lounge users' behavior. J. Travel Tour. Mark. 2019, 36, 29-42. [CrossRef]

50. Kasser, T.; Ryan, R.M. A dark side of the American dream: Correlates of financial success as a central life aspiration. J. Personal. Soc. Psychol. 1993, 65, 410. [CrossRef] 
51. Kim, H.C.; Chua, B.L.; Lee, S.; Boo, H.C.; Han, H. Understanding airline travelers' perceptions of well-being: The role of cognition, emotion, and sensory experiences in airline lounges. J. Travel Tour. Mark. 2016, 33, 1213-1234. [CrossRef]

52. Sheldon, K.M.; Kasser, T. Coherence and congruence: Two aspects of personality integration. J. Personal. Soc. Psychol. 1995, 68, 531. [CrossRef]

53. Ariza-Montes, A.; Arjona-Fuentes, J.M.; Han, H.; Law, R. The price of success: A study on chefs' subjective well-being, job satisfaction, and human values. Int. J. Hosp. Manag. 2018, 69, 84-93. [CrossRef]

54. Kifer, Y.; Heller, D.; Perunovic, W.Q.E.; Galinsky, A.D. The good life of the powerful: The experience of power and authenticity enhances subjective well-being. Psychol. Sci. 2013, 24, 280-288. [CrossRef]

55. Samuel, R.; Bergman, M.M.; Hupka-Brunner, S. The interplay between educational achievement, occupational success, and well-being. Soc. Indic. Res. 2013, 111, 75-96. [CrossRef]

56. Sagiv, L.; Schwartz, S.H. Value priorities and subjective well-being: Direct relations and congruity effects. Eur. J. Soc. Psychol. 2000, 30, 177-198. [CrossRef]

57. Kaplan, A.; Maehr, M.L. Achievement goals and student well-being. Contemp. Educ. Psychol. 1999, 24, 330-358. [CrossRef] [PubMed]

58. Schwartz, S.H. Value orientations: Measurement, antecedents and consequences across nations. In Measuring Attitudes Cross-Nationally: Lessons from the European Social Survey; Sage: London, UK, 2007; pp. 161-193.

59. Job, V.; Langens, T.A.; Brandstätter, V. Effects of achievement goal striving on well-being: The moderating role of the explicit achievement motive. Personal. Soc. Psychol. Bull. 2009, 35, 983-996. [CrossRef] [PubMed]

60. Magee, J.C.; Galinsky, A.D. 8 social hierarchy: The self-reinforcing nature of power and status. Acad. Manag. Ann. 2008, 2, 351-398. [CrossRef]

61. Keltner, D.; Gruenfeld, D.H.; Anderson, C. Power, approach, and inhibition. Psychol. Rev. 2003, 110, 265. [CrossRef] [PubMed]

62. Kraus, M.W.; Chen, S.; Keltner, D. The power to be me: Power elevates self-concept consistency and authenticity. J. Exp. Soc. Psychol. 2011, 47, 974-980. [CrossRef]

63. Sheldon, K.M.; Ryan, R.M.; Rawsthorne, L.J.; Ilardi, B. Trait self and true self: Cross-role variation in the big-five personality traits and its relations with psychological authenticity and subjective well-being. J. Personal. Soc. Psychol. 1997, 73, 1380. [CrossRef]

64. Wood, A.M.; Linley, P.A.; Maltby, J.; Baliousis, M.; Joseph, S. The authentic personality: A theoretical and empirical conceptualization and the development of the authenticity scale. J. Couns. Psychol. 2008, 55, 385. [CrossRef]

65. Diener, E. Subjective well-being: The science of happiness and a proposal for a national index. Am. Psychol. 2000, 55, 34. [CrossRef]

66. Heller, D.; Watson, D.; Ilies, R. The role of person versus situation in life satisfaction: A critical examination. Psychol. Bull. 2004, 130, 574. [CrossRef]

67. Hwang, J.; Han, H. Examining strategies for maximizing and utilizing brand prestige in the luxury cruise industry. Tour. Manag. 2014, 40, 244-259. [CrossRef]

68. Carroll, B.A.; Ahuvia, A.C. Some antecedents and outcomes of brand love. Mark. Lett. 2006, 17, 79-89. [CrossRef]

69. Proksch, M.; Orth, U.R.; Cornwell, T.B. Competence enhancement and anticipated emotion as motivational drivers of brand attachment. Psychol. Mark. 2015, 32, 934-949. [CrossRef]

70. Han, H.; Hyun, S.S. College youth travelers' eco-purchase behavior and recycling activity while traveling: An examination of gender difference. J. Travel Tour. Mark. 2018, 35, 740-754. [CrossRef]

71. Moon, H.; Han, H. Tourist experience quality and loyalty to an island destination: The moderating impact of destination image. J. Travel Tour. Mark. 2019, 36, 43-59. [CrossRef]

72. Sirgy, M.J.; Lee, D.J.; Kressmann, F. A need-based measure of consumer well-being (CWB) in relation to personal transportation: Nomological validation. Soc. Indic. Res. 2006, 79, 337-367. [CrossRef]

73. Han, H.; Yu, J.; Kim, W. Environmental corporate social responsibility and the strategy to boost the airline' s image and customer loyalty intentions. J. Travel Tour. Mark. 2019, 36, 371-383. [CrossRef]

74. Dagger, T.S.; Sweeney, J.C. The effect of service evaluations on behavioral intentions and quality of life. J. Serv. Res. 2006, 9, 3-18. [CrossRef]

75. Han, H.; Hwang, J.; Lee, M.J. The value-belief-emotion-norm model: Investigating customers' eco-friendly behavior. J. Travel Tour. Mark. 2017, 34, 590-607. [CrossRef] 
76. Hwang, J.; Lyu, S.O. The antecedents and consequences of well-being perception: An application of the experience economy to golf tournament tourists. J. Destin. Mark. Manag. 2015, 4, 248-257. [CrossRef]

77. Bartholomew, K.; Horowitz, L.M. Attachment styles among young adults: A test of a four-category model. J. Personal. Soc. Psychol. 1991, 61, 226. [CrossRef]

78. Bowlby, J. On knowing what you are not supposed to know and feeling what you are not supposed to feel. Can. J. Psychiatr. 1979, 24, 403-408. [CrossRef] [PubMed]

79. Whan Park, C.; MacInnis, D.J.; Priester, J.; Eisingerich, A.B.; Iacobucci, D. Brand attachment and brand attitude strength: Conceptual and empirical differentiation of two critical brand equity drivers. J. Mark. Res. 2010, 74, 1-17.

80. Donavan, D.T.; Janda, S.; Suh, J. Environmental influences in corporate brand identification and outcomes. J. Brand Manag. 2006, 14, 125-136. [CrossRef]

81. Park, C.W.; MacInnis, D.J.; Priester, J.R. Beyond attitudes: Attachment and consumer behavior. Seoul J. Bus. 2006, 12, 3-36.

82. Albert, N.; Merunka, D.; Valette-Florence, P. Brand passion: Antecedents and consequences. J. Bus. Res. 2013, 66, 904-909. [CrossRef]

83. Deaton, B.J. A theoretical framework for examining the role of third-party certifiers. Food Control. 2004, 15, 615-619. [CrossRef]

84. Golan, E.; Kuchler, F.; Mitchell, L.; Greene, C.; Jessup, A. Economics of food labeling. J. Consum. Policy. 2001, 24, 117-184. [CrossRef]

85. Darke, P.R.; Chaiken, S.; Bohner, G.; Einwiller, S.; Erb, H.P.; Hazlewood, J.D. Accuracy motivation, consensus information, and the law of large numbers: Effects on attitude judgment in the absence of argumentation. Personal. Soc. Psychol. Bull. 1998, 24, 1205-1215. [CrossRef]

86. Rhoades, D.L.; Waguespack, B. Better safe than service? The relationship between service and safety quality in the US airline industry. Manag. Serv. Qual. Int. J. 1999, 9, 396-401. [CrossRef]

87. Busch, L. The moral economy of grades and standards. J. Rural Stud. 2000, 16, 273-283. [CrossRef]

88. Akdeniz, B.; Calantone, R.J.; Voorhees, C.M. Effectiveness of marketing cues on consumer perceptions of quality: The moderating roles of brand reputation and third-party information. Psychol. Mark. 2013, 30, 76-89. [CrossRef]

89. McKnight, D.H.; Chervany, N.L. What trust means in e-commerce customer relationships: An interdisciplinary conceptual typology. Int. J. Electron. Comm. 2001, 6, 35-59. [CrossRef]

90. Kim, D.; Benbasat, I. Trust-related arguments in internet stores: A framework for evaluation. J. Electron. Commer. Res. 2003, 4, 49-64.

91. Ke, D.; Chen, A.; Su, C. Online trust-building mechanisms for existing brands: The moderating role of the e-business platform certification system. Electron. Commer. Res. 2016, 16, 189-216. [CrossRef]

92. Wang, Y.; Huscroft, J.R.; Hazen, B.T.; Zhang, M. Green information, green certification and consumer perceptions of remanufctured automobile parts. Resour. Conserv. Recycl. 2018, 128, 187-196. [CrossRef]

93. Kajonius, P.J.; Persson, B.N.; Jonason, P.K. Hedonism, achievement, and power: Universal values that characterize the dark triad. Personal. Individ. Differ. 2015, 77, 173-178. [CrossRef]

94. Schultz, P.W.; Zelezny, L.C. Values and proenvironmental behavior: A five-country survey. J. Cross-Cult. Psychol. 1998, 29, 540-558. [CrossRef]

95. Vlachos, P.A.; Theotokis, A.; Pramatari, K.; Vrechopoulos, A. Consumer-retailer emotional attachment: Some antecedents and the moderating role of attachment anxiety. Eur. J. Mark. 2010, 44, 1478-1499. [CrossRef]

96. Hennig-Thurau, T.; Gwinner, K.P.; Gremler, D.D. Understanding relationship marketing outcomes: An integration of relational benefits and relationship quality. J. Serv. Res. 2002, 4, 230-247. [CrossRef]

97. Zeithaml, V.A.; Berry, L.L.; Parasuraman, A. The behavioral consequences of service quality. J. Mark. Res. 1996, 60, 31-46.

98. Jiang, P.; Jones, D.B.; Javie, S. How third-party certification programs relate to consumer trust in online transactions: An exploratory study. Psychol. Mark. 2008, 25, 839-858. [CrossRef]

99. Fornell, C.; Larcker, D.F. Evaluating structural equation models with unobservable variables and measurement error. J. Mark. Res. 1981, 18, 39-50. [CrossRef]

100. Hair, J.F.; Black, W.C.; Babin, B.J.; Anderson, R.E.; Tatham, R.L. Multivariate Data Analysis, 6th ed.; Prentice-Hall: Upper Saddle River, NJ, USA, 2006.

101. Byrne, B.M. Structural Equation Modeling with AMOS; Lawrence Erlbaum Associates: Mahwah, NJ, USA, 2001. 
102. Anderson, J.C.; Gerbing, D.G. Structural equation modeling in practice: A review and recommended two-step approach. Psychol. Bull. 1988, 103, 411-423. [CrossRef]

103. Travel Update. A New Trend in Airline Lounges: Yoga, Stretching and Wellbeing. Available online: https://travelupdate.boardingarea.com/yoga-airline-lounges/ (accessed on 31 March 2019).

104. Jun, P.A.N.G.; Tat, K.H.; Siqing, P.E.N.G. Effects of advertising strategy on consumer-brand relationships: A brand love perspective. Front. Bus. Res. China 2009, 3, 599-620.

105. Zhang, H.; Sun, J.; Liu, F.; Knight, J.G. Be rational or be emotional: Advertising appeals, service types and consumer responses. Eur. J. Mark. 2014, 48, 2105-2126. [CrossRef]

106. Heine, S.J.; Hamamura, T. In search of East Asian self-enhancement. Personal. Soc. Psychol. Rev. 2007, 11, 4-27. [CrossRef] [PubMed]

(C) 2019 by the authors. Licensee MDPI, Basel, Switzerland. This article is an open access article distributed under the terms and conditions of the Creative Commons Attribution (CC BY) license (http://creativecommons.org/licenses/by/4.0/). 